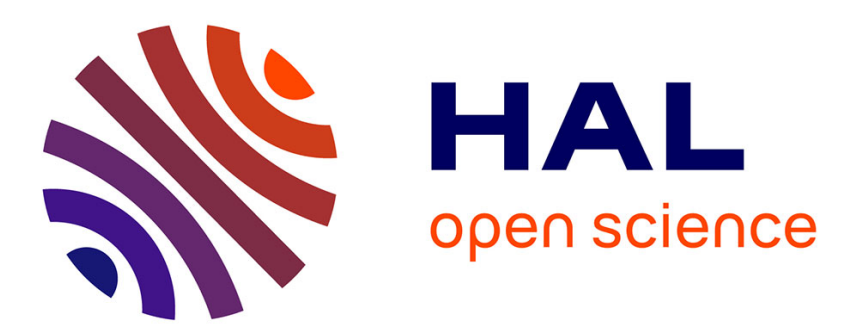

\title{
PEDOT/Superoxide dismutase electrode surface modification for superoxide bioelectrochemical sensing
}

Patricia M Olmos Moya, Silvia Gutiérrez Granados, Fethi Bedioui, Sophie

Griveau

\section{- To cite this version:}

Patricia M Olmos Moya, Silvia Gutiérrez Granados, Fethi Bedioui, Sophie Griveau. PEDOT/Superoxide dismutase electrode surface modification for superoxide bioelectrochemical sensing. Electroanalysis, 2020, 32 (1), pp.29-36. 10.1002/elan.201900396 . hal-03021337

\section{HAL Id: hal-03021337 https://hal.science/hal-03021337}

Submitted on 24 Nov 2020

HAL is a multi-disciplinary open access archive for the deposit and dissemination of scientific research documents, whether they are published or not. The documents may come from teaching and research institutions in France or abroad, or from public or private research centers.
L'archive ouverte pluridisciplinaire HAL, est destinée au dépôt et à la diffusion de documents scientifiques de niveau recherche, publiés ou non, émanant des établissements d'enseignement et de recherche français ou étrangers, des laboratoires publics ou privés. 


\title{
PEDOT/Superoxide dismutase electrode surface modification for superoxide bioelectrochemical sensing
}

\author{
Patricia M. Olmos Moya, ${ }^{\mathrm{a}-\mathrm{b}}$ Silvia Gutiérrez Granados, ${ }^{\mathrm{a}}$ Fethi Bedioui, ${ }^{\mathrm{b}}$ Sophie Griveau ${ }^{\mathrm{b} *}$ \\ a Departamento de Química, DCNE, CAMPUS GUANAJUATO, Universidad de Guanajuato, Guanajuato, México \\ ${ }^{\mathrm{b}}$ Chimie ParisTech-PSL University, Institute of Chemistry for Life and Health Sciences (iCLeHS), CNRS 2027, 75005 \\ Paris, France \\ * e-mail: corresponding author sophie.griveau@ chimieparistech.psl.eu
}

\begin{abstract}
An amperometric biosensor of high enzymatic response to the sensitive and selective detection of superoxide $\left(\mathrm{O}_{2}{ }^{--}\right)$was designed utilizing a drop-coating approach for immobilizing the enzyme superoxide dismutase on Pt electrode modified with a thin layer of poly (3,4-ethylenedioxythiophene) (PEDOT). The PEDOT electrodeposited layer on Pt was characterized by cyclic voltammetry and atomic force microscopy (AFM). Then, drop-coating procedure was chosen for the immobilization of superoxide dismutase, which is incorporated at the electrode surface using a solution containing SOD, glutaraldehyde and bovine serum albumin (optimization composition : SOD 0.1\% - ASB 2\% - GA 2.5\%.) This simple procedure allows forming a reproducible enzymatic biocomposite layer that allows optimal sensitivity and limit of detection for $\mathrm{O}_{2}{ }^{--}$. The synergistic effect integrates an effective conductivity and permoselectivity attributed to the PEDOT, as well as the specificity and selectivity of SOD for the detection of superoxide. A high sensitivity $(0.82 \pm 0.01 \mu \mathrm{A} / \mu \mathrm{M})$ and a low detection limit of $11 \mathrm{nM}$ for $O_{2} \cdot{ }^{-}$were obtained, as well as good selectivity against main interfering biological compounds such as uric acid and ascorbic acid. Our results suggest that the biosensor could be used for the detection and quantification of $\mathrm{O}_{2}{ }^{-{ }^{-}}$in vitro and in vivo.
\end{abstract}

Keywords: Superoxide sensing, Platinum, PEDOT, SOD, amperometry

\section{Introduction}

Among the reactive oxygen species (ROS) at the biological level, the radical superoxide anion $\left(\mathrm{O}_{2}{ }^{-}\right)$, is generated as a reduced intermediate of dioxygen $\left(\mathrm{O}_{2}\right)$ [1],[2]. The main source of superoxide in cells comes from the electron transport chain in the mitochondria and in the endoplasmic reticulum ${ }^{[3]}$. Under normal metabolic conditions, ROS are produced at a rate which does not exceed the capacity of the cell to dismute these species [4],[5]. However, when the production of $\mathrm{O}_{2}{ }^{--}$exceeds the natural capacity of the organism for its dismutation, this oxidant triggers cytotoxicity processes, giving rise to several diseases, including cancer and chronic degenerative diseases ${ }^{[6]}$. Under normal physiological conditions, the basal concentration of $\mathrm{O}_{2}{ }^{-}$- lies between 10 and $100 \mathrm{nmol} / \mathrm{L}$

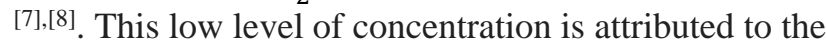
great capacity of superoxide dismutase (SOD) for dismutation and also to its high reactivity with other small molecules ${ }^{[9]}$.

Various technologies have been conceived to indirectly determine the level of $\mathrm{O}_{2}{ }^{-}$, including spin-electron

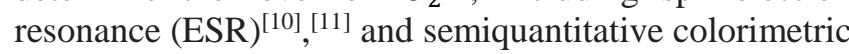
tests ${ }^{[12],[13]}$. However, these technologies can not be applied for the direct detection of $\mathrm{O}_{2}{ }^{-}$in vitro and in vivo. Electrochemical techniques, and more specifically amperometric biosensors, have been used to detect and quantify, directly and in real time $\mathrm{O}_{2}{ }^{--}{ }^{[14]}$. First ${ }^{[15]}$,

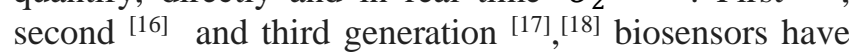
been developed using different types of transducer materials, such as $\mathrm{Pt}, \mathrm{Au}$, and carbon fiber, whose surfaces are modified incorporating different types of nanomaterials and / or certain specific biomolecules. Third generation biosensors based on SOD have high sensitivity and excellent selectivity thanks to the activity of the enzyme to convert $\mathrm{O}_{2}{ }^{-}$to $\mathrm{O}_{2}$ and $\mathrm{H}_{2} \mathrm{O}_{2}$ via a

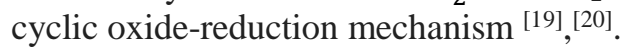

The adequate interfacial communication between the enzyme and the electrode is a key parameter to facilitate the charge transfer. Due to their large surface area, good biocompatibility and excellent stability, conducting polymers are thus used for the immobilization of redox enzymes. The combination of conductive polymer and enzyme can provide a hybrid composition that simultaneously allows a specific recognition of $\mathrm{O}_{2}{ }^{--}$by SOD, as well as a high electron transfer promoted by the polymer [21],[22]. These synergistic effects favor an efficient analytical behavior. Among the main conducting polymers, poly (3, 4-ethylenedioxythiophene) (PEDOT) was already used as an electroconductive platform in the

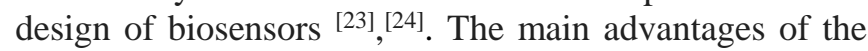
PEDOT are its easy electropolymerisatin in aqueous medium and its stability in a wide range of $\mathrm{pH}^{[25],[26]}$.

The most common methods applied for the immobilization of enzymes, make use of membrane entrapment, cross-linking, covalent binding and physical adsorption [21], [27], ${ }^{[28]}$. The immobilization of SOD [29], [19, ${ }^{24]}{ }^{[17]}$ on the surface, catalyzes the dismutation reaction of $\mathrm{O}_{2}^{-{ }^{-}}$as shown in the following equation:

$$
2 \mathrm{H}^{+}+2 \mathrm{O}_{2}^{\cdot-} \stackrel{\text { SOD }}{\longrightarrow} \mathrm{H}_{2} \mathrm{O}_{2}+\mathrm{O}_{2}
$$

The generated $\mathrm{H}_{2} \mathrm{O}_{2}$ from the enzymatic reaction is reduced at the electrode interface, producing the electrochemical signal associated with the following reaction:

$$
\mathrm{H}_{2} \mathrm{O}_{2}+2 \mathrm{H}^{+}+2 e^{-} \rightarrow 2 \mathrm{H}_{2} \mathrm{O}
$$

In this work, we report on a simple, but effective procedure for the manufacture and characterization of a specific amperometric biosensor using platinum electrode modified by PEDOT and SOD for the detection and quantification of $\mathrm{O}_{2}{ }^{--}$. Brett et al [20] 
have proposed a modification of glassy carbon electrode using multi-walled carbon nanotubes/chitosan, PEDOT and SOD for the detection of superoxide giving interesting performances. In this work, we built on this procedure and adapted it for the modification of platinum electrodes, using PEDOT and $\mathrm{SOD}$, for further transposition in the long run to microelectrodes for measurements of $\mathrm{O}_{2}{ }^{-}$in vitro and in real time ${ }^{[30],[31]}$. Also, the electrode surface modifications were deeply characterized by AFM and cyclic voltammetry. The analytical performances of the modified electrode towards superoxide in terms of sensitivity, selectivity and stability were assessed by chronoamperometry.

\section{Experimental}

\subsection{Chemicals}

Superoxide dismutase enzyme $\mathrm{Cu}-\mathrm{Zn}$ (SOD) from bovine erythrocytes, potassium superoxide $\left(\mathrm{KO}_{2}\right)$, 3,4ethylenedioxythiophene (EDOT), glutaraldehyde (GA), bovine serum albumin (BSA), PBS tablets, uric acid, ascorbic acid, xanthine, $\mathrm{H}_{2} \mathrm{O}_{2}$, sodium XTT, sodium styrene sulfonate (NaSS) and Potassium hexacyanoferrate II $\left(\mathrm{K}_{4}\left[\mathrm{Fe}(\mathrm{CN})_{6}\right]\right)$, were purchased from Sigma-Aldrich and were used as received. ITO substrates were purchased from Delta Technologies and have the following characteristics: $4-10 \Omega$ and dimensions of $150 \times 150 \times 1.1 \mathrm{~mm}$.

The solutions were prepared using ultrapure water (18.2 M $\Omega . c m$ resistivity, LabFlex system, Veolia, France).

The electrochemical experiments were carried out in $0.01 \mathrm{~mol} / \mathrm{L}$ phosphate buffer ( $\mathrm{pH}$ 7.4). For the polymerization of EDOT, $0.1 \mathrm{~mol} / \mathrm{L} \mathrm{NaSS}$ containing $10 \mathrm{mmol} / \mathrm{L}$ EDOT was used.

A $0.1 \% \mathrm{CuZnSOD}$ solution was prepared at the same time, the $2 \%$ BSA protein was integrated (solution A). The $2.5 \%$ glutaraldehyde solution was prepared (solution B). At the end both solutions A and B were mixed, $1 \mu \mathrm{L}$ of this mixture was taken which was placed as drop on the electrode PEDOT / Pt.

\subsection{Preparation of superoxide biosensor}

PEDOT was electrodeposited on $\mathrm{Pt}(\mathrm{d}=1 \mathrm{~mm})$ electrode by sweeping the potential from -0.6 to $1.2 \mathrm{~V}$ vs. SCE at $50 \mathrm{mV} \mathrm{s}^{-1}$ in a $10 \mathrm{mmol} / \mathrm{L}$ EDOT +0.1 $\mathrm{mol} / \mathrm{L} \mathrm{NaSS}$ aqueous solution for 10 cycles. These modified electrode is named as PEDOT/Pt.

Then, the SOD solution was prepared in a bovine albumin serum medium $(0.1 \% \mathrm{SOD}+2 \% \mathrm{BSA})$. It was mixed with a $2.5 \%$ GA solution in a $2: 1(\mathrm{v} / \mathrm{v})$ enzyme: GA ratio, and a $5 \mu \mathrm{L}$ drop was placed on the surface of the PEDOT/Pt electrodes; it was let on to dry for $4 \mathrm{~h}$ at room temperature. Before use, the obtained biosensor was kept immerged in a $0.01 \mathrm{~mol} / \mathrm{L}$ PBS solution, $\mathrm{pH} 7.4$ at $4^{\circ} \mathrm{C}$.

\subsection{Instrumentation}

The electrochemical experiments were carried out with a potentiostat-galvanostat Uniscan instruments (Ametek, France). A three-electrode conventional cell was used as electrochemical system, using disc-shaped Pt as working electrode (1 $\mathrm{mm}$ diameter), platinum wire as counter electrode, and a Saturated Calomel Electrode (SCE) as the reference electrode (Hach Lange, France).

The $\mathrm{pH}$ measurements were carried out with Radiometer analytical (France) pH meter.

An Electronic Scanning Microscope (SEM) model SIGMA-HDVP Field Emission of the brand Carl Zeiss was used to characterize the electropolymerized PEDOT film on ITO substrates.

The Atomic Force Microscopy (AFM) experiments were carried out with an AFM Nanosurf easyscan 2 with a contact tip. The processing of the AFM images was done with the Gwyddion software.

\subsection{Spectrophotometric determination of superoxide}

A stock solution of $\mathrm{KO}_{2}$ was prepared in $\mathrm{NaOH}$ medium, $\mathrm{pH}$ 12.3. Its concentration was determined from the absorbance value at $\lambda=245 \mathrm{~nm}$ using an extinction coefficient of $\varepsilon=2350 \mathrm{M}^{-1} \mathrm{~cm}^{-1}{ }^{[32]}$. The spectra were recorded using a UV-visible spectrophotometer (UVIKON XL, BIO-TEK, France)

\section{Results and discussion}

\subsection{Electropolymerization of EDOT on platinum electrodes.}

Figure1 shows typical successive cyclic voltammograms obtained during the electropolymerization of the PEDOT on Pt electrode.

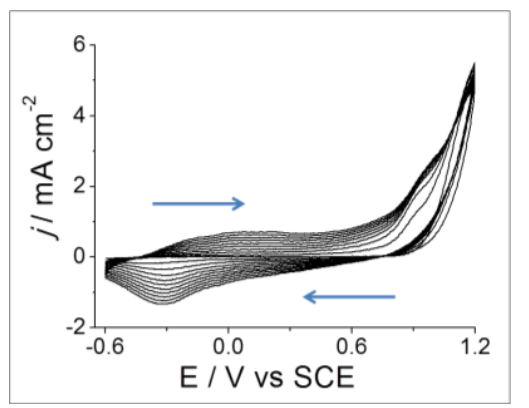

Figure 1. Successive cyclic voltammograms on Pt electrode in aqueous solution containing $10 \mathrm{mmol} / \mathrm{L}$ EDOT and $0.1 \mathrm{M} \mathrm{NaSS}$. Scan rate $50 \mathrm{mVs}^{-1}, 10$ cycles.

The anodic oxidation of EDOT monomer is observed above +0.9 V vs SCE on the first cycle. Then, the characteristic increase of the anodic and cathodic current on each cycle can be observed around $0 \mathrm{~V}$ and $-0.3 \mathrm{~V}$ respectively, indicating the formation of the PEDOT polymer at the electrode surface ${ }^{[33]}$. 


\subsection{Characterization of the PEDOT / Pt modified electrodes}

After electropolymerization, the electrode was characterized by SEM, AFM and cyclic voltammetry. Figure 2-a shows a picture of ITO electrodes modified with PEDOT electrodeposited layer, showing a stable brownish deposit on the electrode surface. Figure 2-b shows the SEM images of the ITO modified electrode. The electrodeposited polymer exhibits a homogeneous coverage on the ITO substrate. Figure 2-c shows the 3D topographic profile of the PEDOT over ITO coating obtained by AFM measurements. A quadratic mean roughness value of $35 \mathrm{~nm}$ and an average thickness of $280 \mathrm{~nm}$ were obtained for the PEDOT film over ITO surface (calculated from triplicate measurements at several points in the PEDOT film). The observed roughness is characteristic of the electrodeposited layer of PEDOT since the roughness of the bare ITO surface is $2 \mathrm{~nm}$ only.
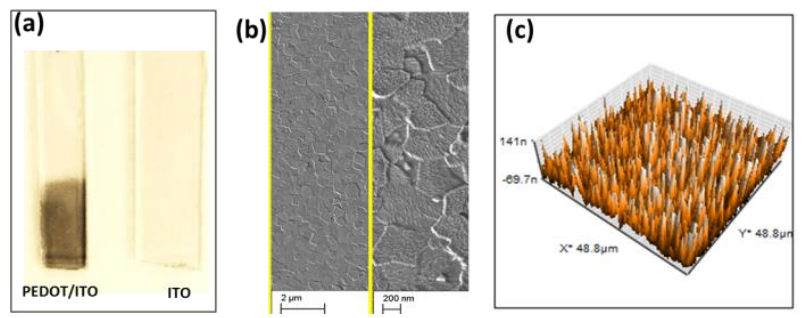

Figure 2. (a) Picture of the ITO substrate modified with PEDOT (left) and ITO without surface modification (right). (b) SEM images of the PEDOT coating on ITO, a "close up" on the polymer from $2 \mu \mathrm{m}$ to $200 \mathrm{~nm}$ is shown. (c) 3D AFM image of $50 \mu \mathrm{m} \times 50 \mu \mathrm{m}$.

Cyclic voltammogram was also recorded at the PEDOT/Pt modified electrode in $5 \mathrm{mM} \mathrm{K} 4\left[\mathrm{Fe}(\mathrm{CN})_{6}\right]$ aqueous solution, and compared to the one obtained at bare Pt electrode, as illustrated on Figure 3-a. This shows the large increase in the intensity of anodic and cathodic peak currents for PEDOT/Pt electrode in comparison to those obtained at bare $\mathrm{Pt}$. This difference can be attributed to the large increase in the electroactive area promoted by the PEDOT film on the Pt substrate, in accordance with the roughness of the PEDOT film deduced from AFM measurements. The slope of 0.5 obtained from the representation $\log I_{p} v s$. $\log v$ at increasing scanning rate (figure 3-b) indicates that the behavior of the soluble redox system is governed by the diffusion at the electrical interface. Figure 3-c shows the evolution of the anodic peak current as a function of the square root of the scan rate (20 to $200 \mathrm{mV} \mathrm{s}^{-1}$ ) for ferrocyanide oxidation on PEDOT / Pt electrode. Using the Randles-Sevcik equation, the values of the electrochemical active surface area of the PEDOT/Pt and Pt bare were estimated as $0.034 \mathrm{~cm}^{2}$ and $0.006 \mathrm{~cm}^{2}$, respectively showing an increase of the surface of 5.6 times between bare and modified electrode.

The stability of the PEDOT / Pt electrodes as a function of time was also investigated. During a period of one month, the peak current intensity signals of ferri/ferrocyanide redox couple did not change. The described results show that the PEDOT / Pt modified electrodes can be an adequate conductive platform in the construction of a SOD / PEDOT / Pt biosensor.
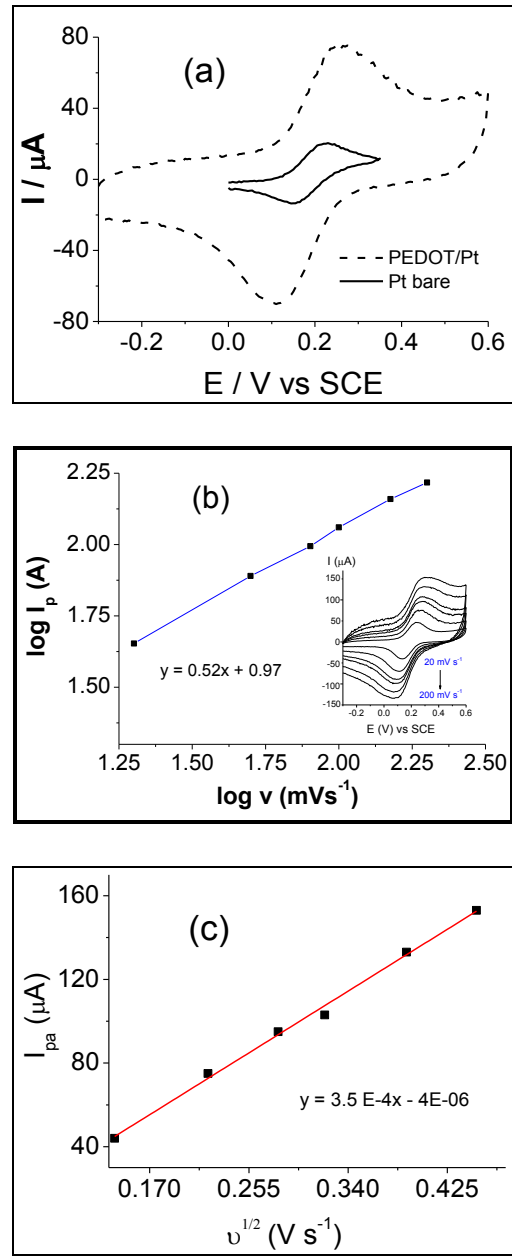

Figure 3. (a) Cyclic voltammograms for bare Pt and PEDOT / Pt electrodes in the presence of $\mathrm{K}_{4}\left[\mathrm{Fe}(\mathrm{CN})_{6}\right] 5 \mathrm{mmol} / \mathrm{L}$ in PBS $\mathrm{pH} 7.4$; scan rate $50 \mathrm{mV} / \mathrm{s}$. (b) Graph of $\log I_{p} v s \log v$ for electrodes modified PEDOT / Pt in the presence of $5 \mathrm{mM}$ $\mathrm{K}_{4}\left[\mathrm{Fe}(\mathrm{CN})_{6}\right]$ in $\mathrm{PBS}$ pH 7.4 at increasing scanning rate. (c) Graph of $I_{p} v s v^{l / 2}$ for PEDOT / Pt electrodes in the presence of $5 \mathrm{mM} \mathrm{K}_{4}\left[\mathrm{Fe}(\mathrm{CN})_{6}\right]$ in PBS pH 7.4, at different scan rates of 20 to $200 \mathrm{mVs}^{-1}$.

\subsection{Electrochemical detection of Superoxide}

\subsubsection{Enzymatic activity of SOD immobilized in the SOD/PEDOT/Pt biosensor}

In solution, SOD efficiently dismutates $\mathrm{O}_{2} .^{-}$to $\mathrm{O}_{2}$ and $\mathrm{H}_{2} \mathrm{O}_{2}$ via a redox cycle attributed to the $\mathrm{Cu}{ }^{\mathrm{I}}$ II metal center couple, which acts as a redox mediator in the $\mathrm{Cu}$ Zn SOD enzyme complex, as follows ${ }^{[29]}$ :

$$
\begin{aligned}
& \operatorname{SOD}\left(\mathrm{Cu}^{I}\right)+\mathrm{O}_{2} \cdot{ }^{-}+2 \mathrm{H}^{+} \rightarrow \operatorname{SOD}\left(\mathrm{Cu}^{I I}\right)+\mathrm{H}_{2} \mathrm{O}_{2} \\
& \operatorname{SOD}\left(\mathrm{Cu}^{I I}\right)+\mathrm{O}_{2}{ }^{-} \rightarrow \operatorname{SOD}\left(\mathrm{Cu}^{I}\right)+\mathrm{O}_{2}
\end{aligned}
$$

The working principle of the biosensor developed here is based on the amperometic signal linked to the electrochemical reduction of $\mathrm{H}_{2} \mathrm{O}_{2}$ generated by the enzymatic reaction (3) [34]. The SOD enzyme was immobilized on the biocompatible coating of PEDOT / $\mathrm{Pt}$, using the drop-coating method, to ensure a good accessibility of the superoxide anion to the 
immobilized SOD enzyme. The enzyme prepared by adding BSA, which helps in the enzymatic activity of SOD. S glutaraldehyde (GA) was integrated as a promoting agent to provide stability to Glutaraldehyde carries out the cross-link lysine residues present in the BAS, gene on its surface. These interactions preve: linkage of GA with the lysine residues cor SOD thus preserving the activity and con the SOD enzyme ${ }^{[35]}$.

$\mathrm{KO}_{2}$ solution in $\mathrm{NaOH}$ was dissolved in superoxide source. The amperometric res 3.3.3. developed biosensor was recorded in PBS 3.3.4. SCE following consecutive additions of $\mathrm{KO}_{2}(0.09 \mu \mathrm{mol} / \mathrm{L}$ each $)$. As illustrated o1 after each addition of $\mathrm{KO}_{2}$, a simultaneous increase of the cathodic current is observed. The biosensor, therefore, efficiently carries out the dismutation of $\mathrm{O}_{2}{ }^{--}$and the continuous detection of $\mathrm{H}_{2} \mathrm{O}_{2}$ as an analytical signal. By introducing catalase in the electrochemical cell allows to ensure that the detected analyte is $\mathrm{H}_{2} \mathrm{O}_{2}$. Indeed, the main action of catalase is the capture of $\mathrm{H}_{2} \mathrm{O}_{2}$ present in the electrochemical cell, converting it into water and oxygen. As observed on Figure 4-a, the addition of catalase induces a large decrease of the analytical signal practically coming back to the baseline.
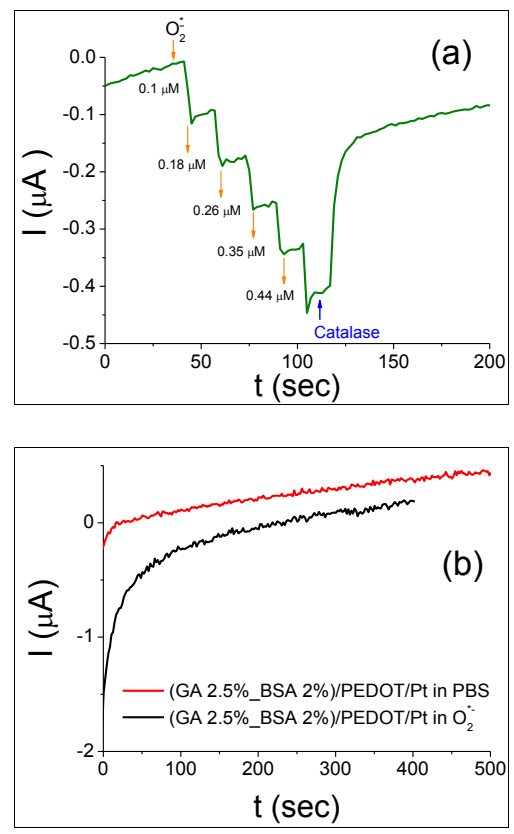

Figure 4. (a) Typical amperometric response for the reaction $\mathrm{H}_{2} \mathrm{O}_{2}+$ Catalase at $-0.30 \mathrm{~V}$ vs SCE in buffer PBS 0.01 $\mathrm{mol} / \mathrm{L}, \mathrm{pH}$ 7.4. The orange arrows represent the sequential addition of $0.1,0.18,0.26,0.35,0.44 \mu \mathrm{mol} / \mathrm{L}$ of $\mathrm{O}_{2} .^{-}$The source of superoxide production was $\mathrm{KO}_{2}$ in $\mathrm{NaOH}$, pH 12.3. The blue arrow indicates the injection of $200 \mu \mathrm{L}$ of $0.1 \%$ catalase. (b) Amperometric response of the modified electrode (GA 2.5\% _BSA 2\%) / PEDOT / Pt (red line) in PBS $0.01 \mathrm{~mol} / \mathrm{L}, \mathrm{pH} 7.4$ and $\mathrm{KO}_{2}$ (black line) to $0.175,0.35$, $0.7,0.875 \mu \mathrm{mol} / \mathrm{L}$ at $-0.30 \mathrm{~V}$ vs SCE in PBS 0.01 M, pH 7.4.

A control experiment was also conducted using a modified electrode in absence of the SOD enzyme (GA $2.5 \%$ BSA 2\%) / PEDOT / Pt electrode) by performing an amperometric analysis upon successive addition of $\mathrm{KO}_{2}$. The typical amperometric response following additions of $\mathrm{KO}_{2}$ aliquots is reported on Figure 4-b. No faradaic signal could be observed that reflects any electrochemical reaction. This result is important since it rules out the intervention of $\mathrm{H}_{2} \mathrm{O}_{2}$ produced by the spontaneous decomposition of $\mathrm{O}_{2}{ }^{-}$in the electrolyte. Indeed, $\mathrm{H}_{2} \mathrm{O}_{2}$ produced in the bulk solution by dismutation of $\mathrm{O}_{2}{ }^{-}$is diluted is the solution explaining that it is not detected. $\mathrm{H}_{2} \mathrm{O}_{2}$, generated from the enzymatic reaction in the vicinity of the membrane, leads to large local concentrations of $\mathrm{H}_{2} \mathrm{O}_{2}$ and is thus detected.

\subsubsection{Analytical performances of the biosensor (SOD0.1\%_BAS2\%_GA2.5\%)/ PEDOT /Pt for the analysis of $\mathrm{O}_{2}{ }^{-}$}

Under normal conditions, the reported $\mathrm{O}_{2}{ }^{-}$concentration levels in the extracellular environment lie between 10 to $100 \mathrm{nmol} / \mathrm{L}^{[7]}$. Consideration of these values is critical, when designing biosensors for superoxide detection in vitro and in vivo. In this work, the optimization of a proposed amperometric biosensor, designed based on (SOD 0.1\%_BAS 2\%_GA 2.5\%) / PEDOT/Pt, has been made.
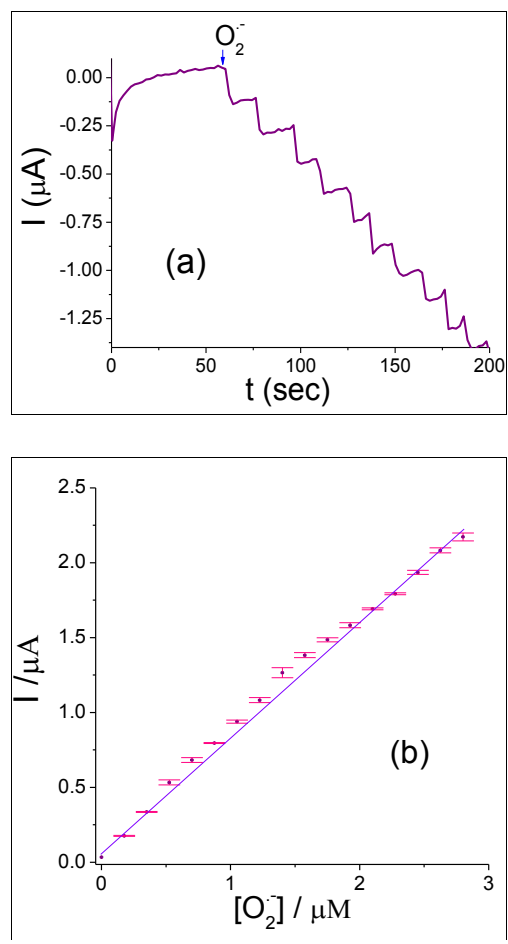

Figure 5. (a) Amperometric response of the biosensor for the successive addition of $\mathrm{O}_{2}{ }^{--}$from an mother solution of $\mathrm{KO}_{2}$ for concentration ranging from 0.175 to $2.8 \mu \mathrm{mol} / \mathrm{L}$. Applied potential $-0.30 \mathrm{~V}$ vs SCE in PBS $0.01 \mathrm{~mol} / \mathrm{L}, \mathrm{pH}$ 7.4. (b) Corresponding calibration curve (cathodic current in absolute value).

Calibration of the biosensor was thus performed by addition of $\mathrm{KO}_{2}$ which produced $\mathrm{O}_{2}{ }^{-}$and measuring the changes in the anodic current as a consequence of the electroquemical reduction of the $\mathrm{H}_{2} \mathrm{O}_{2}$. The amperometric response of the developed biosensor was recorded in PBS at $-0.30 \mathrm{~V}$ vs SCE. The current versus the response time of the electrode for successive additions of $\mathrm{O}_{2}^{--}$is shown in Figure 5a. 
The calibration curve deduced from amperometric analysis is reported on Figure 5-b, showing that the biosensor display a linear response between 0.175 and $2.8 \mu \mathrm{mol} / \mathrm{L}$. The experimental conditions were optimized such that, the analytical parameters of the biosensor show high sensitivity for $\mathrm{O}_{2}{ }^{-}(0.82 \mu \mathrm{A} /$ $\mu \mathrm{M}$ ), and a low detection limit of ca. $11 \mathrm{nmol} / \mathrm{L}$ (using $\mathrm{S} / \mathrm{N}=3$ ). These results suggest the biosensors potential use for monitoring $\mathrm{O}_{2}^{.-}$in vitro and in vivo.

Repeatability was verified constructing three new electrodes and testing them in the same conditions. The points are obtained from the mean of the values for the three electrodes and the error bars represent the standard deviations for each point. The RSD was $0.03 \%$.

\subsection{Selectivity and Stability study}

When designing amperometric biosensors, one of the challenges consists in minimizing and preferably avoiding the effect of electroactive species that may be present, in addition to the target analyte, in the biological fluids. The compounds that can interfere in the amperometric determination of $\mathrm{O}_{2}{ }^{-}$include uric acid (UA), xanthine (XA) and ascorbic acid (AA). To confirm the selectivity of the biosensor to superoxide, we used cyclic voltammetry to evaluate the electrochemical behavior in the presence of specific interferents. The electrochemical data were obtained for each compound at a concentration of $1 \mathrm{mM}$ (Figure 6 ). In the sensing media did not cause a significant signal for UA and XA since the registered $\mathrm{Ip}_{\mathrm{c}}=0$ for these interfering species. However, for AA, a signal of $\mathrm{Ipc}=8.4 \mu \mathrm{A}$ was recorded at $\mathrm{E}_{\mathrm{cat}}=0.01 \mathrm{~V}$. In spite of this, the biosensor remains selective for $\mathrm{O}_{2}{ }^{-}$. This is due first, to the high current intensity signal registered, Ipc $=175 \mu$ at $\mathrm{E}_{\mathrm{cat}}=-0.30 \mathrm{~V}$; and second, because the amperometric measurements are done at a fixed potential $\mathrm{E}_{\mathrm{cat}}=-0.30$, limiting the possibility that notwanted electrochemical reactions occur.

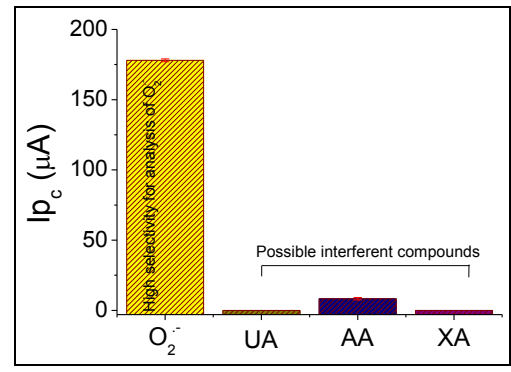

Figure 6. Electrochemical study of possible interferent compounds such as uric acid (UA) and ascorbic acid (AA), xanthine (XA) in the final determination of the anion- radical superoxide.

The amperometric measurements at a fixed potential of $-0.30 \mathrm{~V}$ are presented in Figure 7 . The $\mathrm{O}_{2}{ }^{-{ }^{-}}$was added twice for a final concentration of $25 \mu \mathrm{mol} / \mathrm{L}$ in the cell before the interfering components (UA, AA, XA) were added. These were then added sequentially. This procedure was done to corroborate the amperometric signal for the detection of $\mathrm{O}_{2}{ }^{-}$in a concentration ratio (1:4), $O_{2}{ }^{-}$: interferents $(100 \mu \mathrm{mol} / \mathrm{L})$. It should be noticed that none of these compounds was oxidized or reduced at $\mathrm{E}=-0.30 \mathrm{~V}$ (data not shown). Aliquots of $\mathrm{O}_{2}{ }^{--}$are subsequently injected again, resulting in the recorded signals corresponding to the analyte. This confirms that UA, AA, XA compounds will not be interferents for the final detection of $\mathrm{O}_{2}{ }^{--}$using the biosensor.

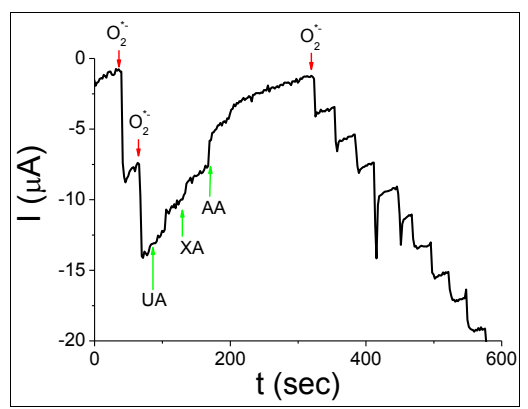

Figure 7. Amperometric response of the interferents (UA, AA, $\mathrm{XA}$ using the modified electrode PEDOT / Pt at $-0.30 \mathrm{~V}$ vs SCE in PBS $0.01 \mathrm{~mol} / \mathrm{L}$. pH 7.4, molar ratio $\mathrm{H}_{2} \mathrm{O}_{2}$ : interfering (1: 4). This information was used to evaluate the electroactive influence of the interferents in the detection of $\mathrm{H}_{2} \mathrm{O}_{2}$.

For the stability study we recorded, during a period of 28 days, the amperometric signals obtained for the detection and quantification of $\mathrm{O}_{2}{ }^{-}$, by means of calibration curves. Was evaluated recording a 10-point calibration plot in the concentration range 0.175 to $1.575 \mu \mathrm{M}$ for $\mathrm{O}_{2}{ }^{-}$three times a week. Figure 8 presents the calibration curves corresponding to the results obtained for current at 8,12 and 28 days after the first use of the biosensor for the analysis. It is observed that the measured current decreases up to $27 \%$ as time progresses. This is reflected in the slight decrease in the sensors sensitivity $(0.597 \mu \mathrm{A} / \mu \mathrm{mol} / \mathrm{L})$, while keeping a good detection limit $(15 \mathrm{nmol} / \mathrm{L})$.

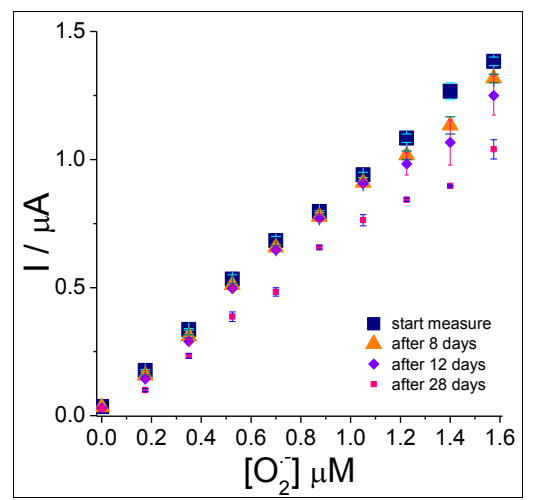

Figure 8. Electrochemical measurements with the biosensor (SOD 0.1\%_BAS 2\%_GA 2.5\%)/PEDOT/Pt in a concentration range $(0.175,0.35,0.7,0.875,1.05,1.225,1.4,1.575) \mu \mathrm{M}$ of $\mathrm{O}_{2}{ }^{--}$. Study of stability after 8,12 and 28 days of the first measurement. 
Table 2. Comparison of results recently reported for biosensors based on the use of SOD enzyme on nanostructured materials (from 2010 to date).

\section{Modified Electrode}

$\mathrm{SOD} / \mathrm{Fe}_{3} \mathrm{O}_{4} \mathrm{NP} / \mathrm{Au}$

$\mathrm{SOD} / \mathrm{CNT} / \mathrm{PPy} / \mathrm{Pt}$

PMMA/PANI-AuNP/SOD-ESCFM

SOD/chitosan AuNP/GCE

SOD/Pt-Pd NP/CNT/SPEG

SOD/Pt-Pd NP/PDARGO

$\mathrm{MeSOD} / \mathrm{AuFs} / \mathrm{GCE}$

SOD/CNT/PEDOT/GCE

$\mathrm{SOD} / \mathrm{PEDOT} / \mathrm{GCE}$

Sty-(SOD-0.5\% GA-2\%PEI)/Pt

Cyt c functionalized nanopipette

(SOD 0.1\%_BAS 2\%_GA 2.5\%)/PEDOT/Pt
$\mathbf{E}_{\text {work }}(\mathbf{V})$

\begin{tabular}{|lccc|}
+0.50 vs. $\mathrm{Ag} / \mathrm{AgCl}$ & $183.1 \mu \mathrm{A} \mathrm{cm}^{-2} \mathrm{mM}^{-1}$ & 3.5 & {$\left[{ }^{[6]}\right.$} \\
\hline 0.07 vs. $\mathrm{Ag} / \mathrm{AgCl}$ & $190.0 \mu \mathrm{A} \mathrm{cm}^{-2} \mathrm{mM}^{-1}$ & 100 & {$[36]$} \\
+0.30 vs. $\mathrm{Ag} / \mathrm{AgCl}$ & $42.5 \mu \mathrm{A} \mathrm{cm}^{-2} \mathrm{mM}^{-1}$ & 300 & {$[37]$} \\
\hline-0.19 vs. $\mathrm{Ag} / \mathrm{AgCl}$ & $6.7 \mu \mathrm{A} \mathrm{cm}^{-2} \mathrm{mM}^{-1}$ & 1.7 & {$[38]$} \\
-0.1 vs. $\mathrm{Ag} / \mathrm{AgCl}$ & $601 \mu \mathrm{A} \mathrm{cm}^{-2} \mathrm{mM}^{-1}$ & 710 & {$[21]$} \\
\hline-0.30 vs. $\mathrm{Ag} / \mathrm{AgCl}$ & $909.7 \mu \mathrm{A} \mathrm{cm}^{-2} \mathrm{mM}^{-1}$ & 2000 & {$[39]$} \\
-0.30 vs. $\mathrm{Ag} / \mathrm{AgCl}$ & $4.2 \mu \mathrm{A} \mathrm{cm}^{-2} \mathrm{mM}^{-1}$ & 92100 & {$[40]$} \\
-0.30 vs. $\mathrm{Ag} / \mathrm{AgCl}$ & $1115 \mu \mathrm{A} \mathrm{cm}^{-2} \mathrm{mM}^{-1}$ & 1000 & {$[20]$} \\
-0.30 vs. $\mathrm{Ag} / \mathrm{AgCl}$ & $184 \mu \mathrm{A} \mathrm{cm}^{-2} \mathrm{mM}^{-1}$ & 8200 & {$[20]$} \\
\hline 0.700 vs. $\mathrm{SCE}$ & $115.86 \mathrm{nA} \mathrm{cm}^{-2} \mu \mathrm{M}^{-1}$ & 63 & {$[7]$} \\
-1 to $1 \mathrm{~V}$ vs. $\mathrm{Ag}$ & ------- & 147 & {$[22]$} \\
-0.30 vs. $\mathrm{SCE}$ & $104.2 \mu \mathrm{A} \mathrm{cm}^{-2} \mu \mathrm{M}^{-1}$ & 11 & This work \\
\hline
\end{tabular}

For sake of comparison, a few analytical parameters of superoxide biosensors based on SOD are summarized in Table 2. Our results are comparable to the ones reported in the recent literature. We must consider, however, the nanostructured materials used for the construction of both biosensors, which require the use of nanoparticles of $\mathrm{Fe}_{3} \mathrm{O}_{4}$ and $\mathrm{Au}$ respectively. Our proposed design and construction of superoxide biosensor has a simpler configuration, exhibits good analytical results for the detection and quantification of $\mathrm{O}_{2}{ }^{-}$in terms of limit of detection, which is the third best LOD reported in the literature.

\section{Conclusions}

A selective and sensitive biosensor for $\mathrm{O}_{2}{ }^{-}$, based on superoxide dismutase, is presented. The sensor was developed by immobilizing the SOD enzyme using the drop coating method on Pt modified with a thin layer of PEDOT. The incorporation of glutaraldehyde and bovine serum albumin provided and preserved the integrity, activity and stability of the enzyme, which contributed to the sensors good sensitivity and analytical parameters. PEDOT electropolymerization on the platinum surface shows an efficient surface coating method that contributes to the synergistic increase in interfacial charge transfer. This in turn, produces a significant increase in analytical signals. In addition, the PEDOT coating acts simultaneously, as a permoselective layer to the passage of $\mathrm{H}_{2} \mathrm{O}_{2}$, and as a barrier to avoid the passage of interfering species such as UA, AA, XA, $\mathrm{KO}_{2}$. This procedure dispenses with the use of sophisticated nanomaterials useful in the manufacture of similar sensing devices. Finally our analytical results indicate that the designed biosensor can be used in the future to monitor $\mathrm{O}_{2} \cdot{ }^{-}$for biological models in vitro and in vivo.

\section{References}

[1] T. P. Stein, Nutrition 2002, 18, 867-871.

[2] N. Azad, Y. Rojanasakul, V. Vallyathan, Journal of Toxicology and Environmental

Health-Part B-Critical Reviews 2008, 11, 1-15.

[3] C. M. Maier, P. H. Chan, Neuroscientist 2002, 8, 323-334.

[4] V. S. Khodade, M. S. Chandra, A. Banerjee, S. Lahiri, M. Pulipeta, R. Rangarajan, H. Chakrapani, Acs Medicinal Chemistry Letters 2014, 5, 777-781.

[5] J. T. Hancock, R. Desikan, S. J. Neill, Biochemical Society Transactions 2001, 29, 345-350.

[6] P. D. Ray, B. W. Huang, Y. Tsuji, Cellular Signalling 2012, 24, 981-990.

[7] M. M. Doran, N. J. Finnerty, J. P. Lowry, Chemistryselect 2017, 2, 4157-4164.

[8] H. A. A. Aly, O. Domenech, Z. M. Banjar, Toxicology and Applied Pharmacology 2012, 261, 134-141.

[9] S. I. Liochev, I. Fridovich, Free Radical Biology and Medicine 2013, 65, 1534-1534.

[10] N. Warwar, A. Mor, R. Fluhr, R. P. Pandian, P. Kuppusamy, A. Blank, Biophysical Journal 2011, 101, 1529-1538.

[11] V. I. Petukhov, L. K. Baumane, I. Y. Kalvinsh, A. P. Skesters, A. A. Silova, B. Rozentale, L. A. Ivanchenko, Bulletin of Experimental Biology and Medicine 2008, 146, 875-877.

[12] H. H. Chu, J. L. Yan, Y. F. Tu, Sensors 2010, 10, 9481-9492.

[13] H. S. Choi, J. W. Kim, Y. N. Cha, C. Kim, Journal of Immunoassay \& Immunochemistry 2006, 27, 31-44.

[14] O. Furman, D. F. Laine, A. Blumenfeld, A. L. Teel, K. Shimizu, I. F. Cheng, R. J. Watts, Environmental Science \& Technology 2009, 43, 1528-1533.

[15] G. Bartosz, Clinica Chimica Acta 2006, 368, 53-76. 
[16] C. Xu, S. Liu, Z. Q. Liu, F. R. Song, S. Y. Liu, Analytica Chimica Acta 2013, 793, 5360.

[17] Z. F. Deng, Q. Rui, X. Yin, H. Q. Liu, Y. Tian, Analytical Chemistry 2008, 80, 58395846.

[18] L. Campanella, G. Favero, L. Persi, M. Tomassetti, Journal of Pharmaceutical and Biomedical Analysis 2000, 23, 69-76.

[19] S. Kintzios, I. Marinopoulou, G. Moschopoulou, O. Manganab, K. Nomikou, K. Endo, I. Papanastasiou, A. Simonian, Biosensors \& Bioelectronics 2006, 21, 1365-1373.

[20] M. Braik, M. M. Barsan, C. Dridi, M. Ben Ali, C. M. A. Brett, Sensors and Actuators B-Chemical 2016, 236, 574-582.

[21] X. Zhu, X. H. Niu, H. L. Zhao, J. Tang, M. B. Lan, Biosensors \& Bioelectronics 2015, 67, 79-85.

[22] R. E. Ozel, G. Bulbul, J. Perez, N. Pourmand, Acs Sensors 2018, 3, 1316-1321.

[23] Y. Tian, L. Q. Mao, T. Okajima, T. Ohsaka, Analytical Chemistry 2004, 76, 4162-4168.

[24] J. W. Di, S. P. Bi, M. Zhang, Biosensors \& Bioelectronics 2004, 19, 1479-1486.

[25] W. Qian, Q. H. Luo, Z. L. Wang, M. C. Shen, Journal of Electroanalytical Chemistry 2004, 568, 143-149.

[26] K. Thandavan, S. Gandhi, S. Sethuraman, J. B. B. Rayappan, U. M. Krishnan, Sensors and Actuators B-Chemical 2013, 176, 884892.

[27] S. Kakhki, M. M. Barsan, E. Shams, C. M. A. Brett, Electroanalysis 2013, 25, 77-84.

[28] V. Pifferi, M. M. Barsan, M. E. Ghica, L. Falciola, C. M. A. Brett, Electrochimica Acta 2013, 98, 199-207.

[29] J. Storsberg, H. Ritter, H. Pielartzik, L. Groenendaal, Advanced Materials 2000, 12, 567-569.

[30] A. Elschner, W. Lovenich, Mrs Bulletin 2011, 36, 794-798.

[31] C. J. Brabec, A. Cravino, D. Meissner, N. S. Sariciftci, T. Fromherz, M. T. Rispens, L. Sanchez, J. C. Hummelen, Advanced Functional Materials 2001, 11, 374-380.

[32] M. Hayyan, M. A. Hashim, I. M. AlNashef, Chemical Reviews 2016, 116, 3029-3085.

[33] B. Y. Lu, L. Q. Qin, W. L. Chen, S. Chen, J. K. $\mathrm{Xu}$, International Journal of Electrochemical Science 2014, 9, 45354547.

[34] P. J. Hart, M. M. Balbirnie, N. L. Ogihara, A. M. Nersissian, M. S. Weiss, J. S. Valentine, D. Eisenberg, Biochemistry 1999, 38, 2167-2178.

[35] J. Cruz, O. Barbosa, R. C. Rodrigues, R. Fernandez-Lafuente, R. Torres, C. Ortiz, Journal of Molecular Catalysis BEnzymatic 2012, 80, 7-14.

[36] S. Rajesh, A. K. Kanugula, K. Bhargava, G. Ilavazhagan, S. Kotamraju, C. Karunakaran,
Biosensors \& Bioelectronics 2010, 26, 689695.

[37] P. Santhosh, K. M. Manesh, S. H. Lee, S. Uthayakumar, A. I. Gopalan, K. P. Lee, Analyst 2011, 136, 1557-1561.

[38] L. Wang, W. Wen, H. Y. Xiong, X. H. Zhang, H. S. Gu, S. F. Wang, Analytica Chimica Acta 2013, 758, 66-71.

[39] J. Tang, X. Zhu, X. H. Niu, T. T. Liu, H. L. Zhao, M. B. Lan, Talanta 2015, 137, 18-24.

[40] Q. Ye, W. Li, Z. Wang, L. M. Zhang, X. S. Tan, Y. Tian, Journal of Electroanalytical Chemistry 2014, 729, 21-26. 